\title{
Microstructural and electrical characterization of Mn-Co spinel protective coatings for solid oxide cell interconnects
}

Molin, S.; Sabato, A. G.; Bindi, M.; Leone, P.; Cempura, G.; Salvo, Milena; Cabanas Polo, Sandra; Boccaccini, A. R.; Smeacetto, Federico

Published in:

Journal of the European Ceramic Society

Link to article, DOI:

10.1016/j.jeurceramsoc.2017.07.011

Publication date:

2017

Document Version

Peer reviewed version

Link back to DTU Orbit

Citation (APA):

Molin, S., Sabato, A. G., Bindi, M., Leone, P., Cempura, G., Salvo, M., Cabanas Polo, S., Boccaccini, A. R., \& Smeacetto, F. (2017). Microstructural and electrical characterization of Mn-Co spinel protective coatings for solid oxide cell interconnects. Journal of the European Ceramic Society, 37(15), 4781-4791.

https://doi.org/10.1016/j.jeurceramsoc.2017.07.011

\section{General rights}

Copyright and moral rights for the publications made accessible in the public portal are retained by the authors and/or other copyright owners and it is a condition of accessing publications that users recognise and abide by the legal requirements associated with these rights.

- Users may download and print one copy of any publication from the public portal for the purpose of private study or research.

- You may not further distribute the material or use it for any profit-making activity or commercial gain

- You may freely distribute the URL identifying the publication in the public portal 


\section{Accepted Manuscript}

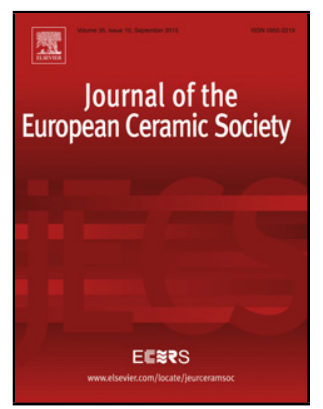

Title: Microstructural and electrical characterization of Mn-Co spinel protective coatings for solid oxide cell interconnects

Authors: S. Molin, A.G. Sabato, M. Bindi, P. Leone, G.

Cempura, M. Salvo, S. Cabanas Polo, A.R. Boccaccini, F.

Smeacetto

PII:

DOI:

Reference:

To appear in:

Received date:

Revised date:

Accepted date:
S0955-2219(17)30498-3

http://dx.doi.org/doi:10.1016/j.jeurceramsoc.2017.07.011

JECS 11368

Journal of the European Ceramic Society

5-6-2017

$14-7-2017$

$16-7-2017$

Please cite this article as: Molin S, Sabato AG, Bindi M, Leone P, Cempura G, Salvo M, Polo S Cabanas, Boccaccini AR, Smeacetto F.Microstructural and electrical characterization of $\mathrm{Mn}-\mathrm{Co}$ spinel protective coatings for solid oxide cell interconnects.Journal of The European Ceramic Society http://dx.doi.org/10.1016/j.jeurceramsoc.2017.07.011

This is a PDF file of an unedited manuscript that has been accepted for publication. As a service to our customers we are providing this early version of the manuscript. The manuscript will undergo copyediting, typesetting, and review of the resulting proof before it is published in its final form. Please note that during the production process errors may be discovered which could affect the content, and all legal disclaimers that apply to the journal pertain. 


\title{
Microstructural and electrical characterization of Mn-Co spinel protective coatings for solid oxide cell interconnects
}

S. Molin ${ }^{1}$, A. G. Sabato ${ }^{2}$, M. Bindi ${ }^{3}$, P. Leone ${ }^{4}$, G. Cempura ${ }^{5}$, M. Salvo ${ }^{2}$, S. Cabanas Polo $^{6}$, A. R. Boccaccini $^{6}$, F. Smeacetto ${ }^{2, *}$

${ }^{1}$ Department of Energy Conversion and Storage, Technical University of Denmark, Risø Campus, 4000 Roskilde, Denmark

${ }^{2}$ Department of Applied Science and Technology, DISAT, Politecnico di Torino, Corso Duca degli Abruzzi 24, 10129 Torino, Italy

${ }^{3}$ Edison Research \& Development Center, Edison S.p.A., Trofarello (Torino), Italy

${ }^{4}$ Department of Energy, DENERG, Politecnico di Torino, Corso Duca degli Abruzzi 24, 10129 Torino, Italy

${ }^{5}$ AGH University of Science and Technology, al. Mickiewicza 30, 30-059 Krakow, Poland

${ }^{6}$ Department of Materials Science and Engineering, University of Erlangen-Nuremberg, Cauerstr. 6, 91058 Erlangen, Germany

*Corresponding author: Federico Smeacetto, Politecnico di Torino, Corso Duca degli Abruzzi 24, 10129 Torino, Italy; e-mail federico.smeacetto@polito.it.Tel 00390110904756 Fax: 00390110904669

\begin{abstract}
Electrophoretic deposition, thermal co-evaporation and RF magnetron sputtering methods are used for the preparation of Mn-Co based ceramic coatings for solid oxide fuel cell steel interconnects. Both thin and relatively thick coatings $(1-15 \mu \mathrm{m})$ are prepared and characterised for their potential protective behaviour. Mn-Co coated Crofer22APU samples are electrically tested for 5000 hours at $800^{\circ} \mathrm{C}$ under a $500 \mathrm{~mA} \mathrm{~cm}^{-2}$ current load to determine their Area Specific Resistance increase due to a growing chromia scale. After tests, samples are analysed by scanning and transmission electron microscopy. Analysis is focused on the potential chromium diffusion to or through the coating, the oxide scale thickness and possible reactions at the interfaces. The relationships between the coating type, thickness and effectiveness are reviewed and discussed. Out of the three Mn-Co coatings compared in this study, the one deposited by electrophoretic deposition presents the best protection against $\mathrm{Cr}$ diffusion and offers long term stability.
\end{abstract}

Keywords: solid oxide cell, electrophoretic deposition, protective coating, area specific resistance, microstructure;

\section{Introduction}

Solid Oxide Fuel Cells (SOFCs) and Solid Oxide Electrolysis cells (SOECs) are efficient chemical energy conversion devices. Single cell consist of two porous electrodes: the anode and the cathode 
with a dense ionically conductive electrolyte in-between [1-3]. Single cell has a working voltage of $\sim 0.7 \mathrm{~V}$, so to improve the output power, several cells have to be connected together by the interconnect plates, forming a stack. Currently, metallic alloys have been widely adapted as materials for the interconnects. They ensure both a physical and electrical contact with the cells and keep the fuel separated from the oxidant gases [4-6].

Among the available alloys, chromia-forming ferritic steels are chosen as they form an oxide with a sufficient electrical conductivity at high temperatures and have a coefficient of thermal expansion (CTE) similar to other cell components [7-10]. Under SOC relevant conditions, $\mathrm{Cr}_{2} \mathrm{O}_{3}$ reacts with water molecules by forming volatile compounds. These Cr-containing species can poison the air electrode and subsequently cause degradation in the stack. The formation of volatile chromium compounds, such as $\mathrm{CrO}_{3}$ or $\mathrm{CrO}_{2}(\mathrm{OH})_{2}$ that can precipitate on the cathode surface affecting its electrochemical activity should be as low as possible [11-13]. In order to reduce the evaporation and limit corrosion rate, protective coatings are typically used on the oxygen side.

The increase of the Area Specific Resistance (ASR) of the metallic interconnects is caused by the growth of the oxide scale during high temperature exposure to both the reducing and oxidizing atmospheres. The electrical conductivity of the oxide scale (chromia and $(\mathrm{Mn}, \mathrm{Cr})_{3} \mathrm{O}_{4}$ ) is much lower in comparison to the metallic substrate and thus its growth results in monotonically increasing ASR values [14]. The oxide scale should not be thicker than $10 \mu \mathrm{m}$, otherwise the risk of spallation will occur with a further contribution to increase the electrical resistivity of the interconnect.

Among different potential protective materials, some offer lowering the corrosion rates and some have good chromium blocking properties. For example, Molin et al. evaluated a $\mathrm{Co}_{3} \mathrm{O}_{4} / \mathrm{LSM}$ based dual layer coating, that successfully limited the corrosion rate of the interconnect but was permeable to $\mathrm{Cr}$ diffusion. Thus coatings both lowering the chromium diffusion and limiting oxide growth with good mechanical properties are required [15-17].

Very good protection against $\mathrm{Cr}$ evaporation has been reported for the $(\mathrm{Mn}, \mathrm{Co})_{3} \mathrm{O}_{4}$ spinel. It has sufficient electrical conductivity, compatible CTE and low Cr diffusion. Although this coating has been extensively studied and it has been demonstrated to be highly effective in reducing corrosion rates, still no clear correlation exists between the coating thickness, preparation methods and the protective properties.

$(\mathrm{Mn}, \mathrm{Co})_{3} \mathrm{O}_{4}$ spinel coatings of different thickness have been produced by many different deposition techniques: slurry deposition of ceramic powders [15,18-20], electrodeposition followed by oxidation [21-23], physical vapor deposition (PVD), thermal oxidation [24,25] and thermal spray [26-29].

For the screening of coating materials by different deposition methods, the electrical characterization of the coated interconnects is of crucial importance. Coated alloys must possess low initial Area Specific Resistance (ASR) and exhibit low ASR increase rate, thus providing low ohmic contribution to the stack. The upper limit for the interconnect ASR can be considered equal to $\sim 100 \mathrm{~m} \Omega \mathrm{cm}^{2}$ [30]. Mn-Co spinels have been electrically characterized in different papers [31-37]. A post heat-treatment 
is normally required in processes such as EPD [38] or conventional wet ceramic techniques [39], in order to remove organic binders and to sinter deposited particles, while this is not the case for sputtering or other thin film deposition methods [40,41].

The objective of the present work is to compare three different Mn-Co based coatings on a Crofer 22 APU substrate. Coatings are produced by electrophoretic deposition (EPD), RF sputtering and thermal co-evaporation methods and evaluated by measuring their electrical properties and characterizing their microstructures before and after the long term electrical tests.

Electrophoretic deposition (EPD) is a versatile and cost-efficient fabrication process extensively used for the processing of ceramic coatings [42-45]. This electric field assisted process employs the movement of charged particles towards a charged electrode in an electric field [46,47]. EPD technique offers the possibility to deposit a wide variety of materials (ceramics, metals, glasses etc.) with a broad range of particle sizes ( $\mathrm{nm}$ to hundreds of $\mu \mathrm{m}$ ). This relatively simple technique offers an easy scalingup to industrially applicable dimensions $[48,49]$. EPD offers an easy control of the coating thickness and good surface coverage even for complex shapes [50,51].

EPD has been previously used to deposit protective coatings based on the Mn,Co spinel. For example, Zhang et al. [38] have used the EPD method for the deposition of the $(\mathrm{Mn}, \mathrm{Co})_{3} \mathrm{O}_{4}$ spinel coatings on T441 steel. They have studied the effects of the applied voltage and sintering on the coating quality and ASR. They have found that a sintering with a reducing step is beneficial for lowering of the ASR. In another work, Zhang et al. [52] reported on the microstructure, oxidation kinetics, and electrical behaviour of Mn-Co spinel coating produced by EPD on Crofer 22 APU steel. They have also used the reduction step during the sintering (in argon) to obtain denser samples with low $\mathrm{Cr}$ permeation. Other authors [22,53] reported on Co and Mn spinel based produced by electrodeposition. Electrophoretic deposition technique was also used by M. Mirzaei et al. [54] and Abdoli et al. [55] to prepare $\mathrm{MnCo}_{2} \mathrm{O}_{4}$ spinel films on AISI 430 stainless steel; the oxidation behavior and electrical properties of the coated specimens were studied for a total of $500 \mathrm{hrs}$. EPD was also employed by Yoo et al. [56] to coat $\left(\mathrm{Mn}_{1.5} \mathrm{Co}_{1.5}\right) \mathrm{O}_{4}$ spinel layer and $\mathrm{La}_{0.8} \mathrm{Sr}_{0.2} \mathrm{MnO}_{3}$ layer on Crofer $22 \mathrm{APU}$; the ASR tests were conducted up to $110 \mathrm{hrs}$. EPD depositions and relative sintering processing parameters used in this study were optimized in a previous work by the same authors [57].

Thermal co-evaporation technique was also used to produce a thin $\mathrm{Mn}_{1.5} \mathrm{Co}_{1.5} \mathrm{O}_{4}$ coating on Crofer 22 APU. The main advantage of this technique is the basically uniform deposition over large areas combined with a high deposition rate. This technique has been mainly used for the preparation of superconductor materials and a previous publication [58] reports the use of this technique to produce $\mathrm{Mn}_{1.5} \mathrm{Co}_{1.5} \mathrm{O}_{4}$ coatings on a Crofer 22 APU substrate.

RF Magnetron sputtering is a powerful technique for producing different kinds of coatings. It has some advantages such as a high deposition rate, easy sputtering of any metal, alloy or compound, the formation of high-purity films with high adhesion to the substrates. Mn-Co coatings with thickness of $800 \mathrm{~nm}, 1500 \mathrm{~nm}, 3000 \mathrm{~nm}$ were deposited on SUS430 steel by magnetron sputtering. Oxidation 
behaviour and ASR of coated samples were investigated after at $800^{\circ} \mathrm{C}$ in air up to $1000 \mathrm{hrs}$. These results showed a $\mathrm{Mn}_{40} \mathrm{Co}_{60}$ coating $1500 \mathrm{~nm}$ thick as the best candidate for long term SOFC applications [59]. Magnetron sputtering was also used to fabricate $\mathrm{Co} / \mathrm{Mn} / \mathrm{Cu}$ protective coatings on channelled Crofer22APU and F17TNb metallic interconnects [60]. $(\mathrm{Co}, \mathrm{Mn}, \mathrm{Cu})_{3} \mathrm{O}_{4}$-based protective coatings were formed after oxidation; for both Crofer 22 APU and F17TNb substrates, Co-Cu based coatings showed the lowest ASR (12-15 $\mathrm{m} \Omega \mathrm{cm}^{2}$ for a duration of 500-900 hrs).

In this work three different deposition methods were used to prepare Mn-Co spinel coatings on the Crofer 22 APU steel substrates and were evaluated for their long term electrical Area Specific Resistance behaviour. After the test, samples were microstructurally characterized.

\section{Experimental}

Crofer 22 APU steel (ThyssenKrupp) coupons of $20 \times 40 \times 0.3 \mathrm{~mm}^{3}$ were used as substrate materials for subsequent coating depositions. Prior to depositions, the Crofer 22 APU substrates were ultrasonically cleaned in acetone in order to remove any impurities.

Thermal co-evaporation $\mathrm{Mn}$-Co thin coatings were prepared by thermal co-evaporation technique using a Theva GmbH evaporation system. Mn (99.8\% purity) and Co (99.9\%), from Chempur GmbH, were positioned in two separate boat crucibles (alumina coated tungsten for the Co metal evaporation and conventional tantalum boat for the manganese evaporation) and put in the evaporation chamber. The co-evaporation process was carried out by resistively heating the respective boat crucibles with the applied power. The deposition pressure of about $2 \times 10^{-5}$ mbar was maintained by two turbo molecular vacuum units during the $30 \mathrm{~min}$ of evaporation. The substrate holder was heated at $600^{\circ} \mathrm{C}$. After the thermal co-evaporation deposition, the samples were annealed in-situ at $800^{\circ} \mathrm{C}$ for 30 minutes $\left(\mathrm{O}_{2}, 1 \mathrm{~atm}\right)$ in order to form the Mn-Co spinel coating with the selected stoichiometry.

RF sputtering depositions were processed by a Kolzer DGK36 using a commercial 7 inches diameter disk-shaped $\mathrm{Mn}_{1.5} \mathrm{Co}_{1.5} \mathrm{O}_{4}$ target; the pressure inside the chamber was $3 \times 10^{-4}$ mbar, a power of 0.5 $\mathrm{kW}$ and a deposition time of $1.5 \mathrm{hrs}$ were used. The deposition was processed on both Crofer $22 \mathrm{APU}$ substrates at room temperature and on samples heated at $400^{\circ} \mathrm{C}$.

Commercially available $\mathrm{Mn}_{1.5} \mathrm{Co}_{1.5} \mathrm{O}_{4}$ spinel powder (mean particle size of $0.36 \mu \mathrm{m}$ and a specific surface area of $12.0 \mathrm{~m}^{2} / \mathrm{g}$ ) was obtained from American Elements (USA). $1 \mathrm{~mm}$ thick Crofer $22 \mathrm{APU}$ samples were used as substrates for the deposition by EPD. The spinel powder was dispersed in a mixture of ethanol and deionized water (volume ratio of $60 / 40$ of $\mathrm{EtOH} / \mathrm{H}_{2} \mathrm{O}$ ) with a solid content of $37.5 \mathrm{~g} \mathrm{~L}^{-1}$. The suspension was homogenized by placing in an ultrasonic bath for 15 minutes (Bandelin Sonorex, Germany). For each deposition, new suspensions were used. A 316 stainless steel sheet with similar dimensions to the Crofer 22 APU substrate was used as the counter electrode in the EPD cell. The distance between both electrodes was kept constant at $10 \mathrm{~mm}$ which results in electric field strength of $50 \mathrm{~V} \mathrm{~cm}^{-1}$. For optimized deposits, 20 secs of deposition time was used. Coated samples 
were removed from the suspensions after switching off the voltage and were subsequently dried at room temperature in air for $24 \mathrm{~h}$.

$\mathrm{Mn}_{1.5} \mathrm{Co}_{1.5} \mathrm{O}_{4}$ coated Crofer $22 \mathrm{APU}$ samples were sintered at $1000^{\circ} \mathrm{C}$ for 2 hours (heating rate $10^{\circ} \mathrm{C}$ $\min ^{-1}$ ) in static air atmosphere to obtain a homogeneous $\mathrm{Mn}_{1.5} \mathrm{Co}_{1.5} \mathrm{O}_{4}$ layer.

The Area Specific Resistance of the spinel coated and uncoated Crofer 22 APU alloys was measured at $800^{\circ} \mathrm{C}$ in stagnant air with an applied current density of $500 \mathrm{~mA} \mathrm{~cm}^{-2}$. The setup used for the ASR measurement is described in more details in [61]. In order to measure voltage drop on a single interface, platinum wire was welded to the alloy, which served as an "internal" reference electrode. A second electrode (flattened platinum wire) was placed on the $\mathrm{La}_{0.85} \mathrm{Sr}_{0.15} \mathrm{MnO}_{3}$ (LSM) contacting plate which was spray-coated with LSM contact layer in order to ensure a good contact with the sample surface. The voltage drop (used for calculation of the ASR) was measured between the alloy (reference electrode) and the LSM plate (second platinum wire) placed on the alloy. For current distribution, bottom and top LSM plates were contacted by a gold foil. Current density was monitored by measuring a voltage drop on a reference resistor. For comparison purposes, an uncoated Crofer 22 APU was measured in the same setup.

$\mathrm{X}$-ray diffractometry (XRD) analysis of the as-prepared samples was performed using Bruker D8 Advance system with $\mathrm{CuK}_{\alpha}$ radiation. Measurements were carried out in a standard $2 \theta$ configuration at room temperature in the range $20^{\circ}-80^{\circ}$, with $0.01^{\circ}$ step and 2 seconds/step counting time.

Scanning electron microscopy (SEM) observations have been performed using a table-top Hitachi TM3000 microscope or high resolution field emission microscope Zeiss Supra35 equipped with an energy dispersive x-ray analysis based on Bruker SDD detectors. For quantification, Quantax70 or Esprit 1.9 software from Bruker was used. Both the surfaces and cross sections were analyzed. For preparation of the cross-sections, samples were embedded in epoxy (EpoFix, Struers, Denmark), cut and polished down to $1 \mu \mathrm{m}$ diamond paste finish.

Specimens for transmission electron microscopy (TEM) investigations (lamellas) were prepared using Zeiss NEON CrossBeam 40 EsB Focus Ion Beal (FIB) instrument. Lamellas were cut from chosen regions of polished cross-sectional specimens. The TEM investigations were carried out using FEI Tecnai G2 (Selected Area Electron Diffraction - SAED) and a FEI Titan Cubed G2 60-300 - a probe Cs corrected (S)TEM for analytical high resolution equipped with ChemiSTEM EDX system based on a 4 windowless Silicon Drift Detectors (Super X) - (High Angle Annular Dark Field - Scanning Transmission Electron Microscopy (HAADF) and energy dispersive X-ray spectrometry (EDS)). Phase identification was performed by means of electron diffraction and EDS. The SAED patterns were interpreted using JEMS (Java Electron Microscopy Software) software.

\section{Results and Discussion}

Microstructures of the as produced coatings 
Coatings in the as-produced state were analysed by x-ray diffractometry and by scanning electron microscopy of the surfaces and polished cross-sections.

Surface XRD analysis results, presented in Figure 1, show the presence of $(\mathrm{Mn}, \mathrm{Co})_{3} \mathrm{O}_{4}$ spinel phase on all samples. Thin coatings, though processed only at room temperature or at $400^{\circ} \mathrm{C}$, showed similarly crystallized layers. Both the cubic $\mathrm{MnCo}_{2} \mathrm{O}_{4}$ and tetragonal $\mathrm{Mn}_{2} \mathrm{CoO}_{4}$ phases have been detected as expected for the $\mathrm{Mn}_{1.5} \mathrm{Co}_{1.5} \mathrm{O}_{4}$ composition. At room temperature $\mathrm{Mn}_{1.5} \mathrm{Co}_{1.5} \mathrm{O}_{4}$ is a mixed spinel, consisting of these two phases. During heating to high temperatures, it transforms to a purely cubic $\mathrm{MnCo}_{2} \mathrm{O}_{4}$ phase. Full transformation to the cubic phase can occur around $400^{\circ} \mathrm{C}$ [62]. Some peaks in the spectra from the EPD sample can be possibly ascribed to the $\mathrm{Cr}_{2} \mathrm{O}_{3}$. However its peaks overlap with the spinel peaks. Additionally, due to some possible $\mathrm{Cr}$, Mn diffusion, peaks are slightly shifted in comparison to the reference positions. The major difference between the spectra of the thin coatings and the EPD coating is the presence of a strong peak from the alloy for the thin coatings, whereas for the thicker EPD coating this peak has relatively low intensity.

Surface SEM images of the as-prepared coatings are presented in Figure 2 A-D. The EPD coating looks quite porous on the surface, exhibiting well-connected grains with size around 1 micron. Figure $2 \mathrm{~B}$ and $\mathrm{C}$, presenting samples obtained by RF sputtering (with un-heated and heated substrates, respectively), shows a dense structure covering uniformly the whole sample surface. At low magnification image, due to the small coating thickness, irregularities of the substrate can be still visible. At higher magnification images octahedral grains on the surface are evident; these octahedral crystals are smaller than 1 micron in both cases, with slightly sharper shape (edges) on the heat-treated sample. The sample prepared by thermal co-evaporation (Figure $1 \mathrm{D}$ ) shows very fine grains, hard to observe with high resolution SEM. Grains are smaller than $50 \mathrm{~nm}$ and also cover the surface very well. On the low magnification SEM image some small "pinholes" on the surface are visible for this sample.

Analysis of coatings cross sections in the as-prepared state, shown in Figure 3 A-D, indicates a clear difference in thickness of the EPD and the other coatings. The EPD coated sample, shown in Figure $3 \mathrm{~A}$, has a 15 micron thick Mn-Co layer with a more porous layer in the outer part. A dense layer is clearly visible in the inner coating area, which is in direct contact with the oxide scale formed on the Crofer $22 \mathrm{APU}$ during the heat treatment at $1000{ }^{\circ} \mathrm{C}$ for 2 hours in air (necessary for coating densification). This reaction layer is typical for air processed coatings [61,63]. As determined by point EDS analysis, the formed oxide is composed purely of chromium oxide ( $\mathrm{Cr} 35.6$ at.\%, O 56.4 at.\%). The thickness of this layer after sintering is $\sim 1.5 \mu \mathrm{m}$. The reaction layer that formed at the top the chromia has a similar thickness. Point analysis detected $\sim 20$ at.\% Mn, 20 at.\% Co and 1 at.\% of Cr, 
the rest being oxygen (with some potential contribution from the surrounding layers due to the small interaction volume).

Thin coatings, showed in Figure 1 B,C,D, have thicknesses between $1 \mu \mathrm{m}$ and $1.5 \mu \mathrm{m}$. Both sputtered samples (C and D) contain a small amount of isolated micro pores $\sim 0.1 \mu \mathrm{m}$ in size, that are likely formed as a consequence of gas entrapment during the deposition. A transversal crack is present in the coating produced by sputtering on the substrate at room temperature. Furthermore the inner area is more porous than the outer one; this can be likely due to a predominance of the shadowing effect during sputtering deposition. Heating of the substrate during the deposition is mainly aimed at increasing the surface diffusion coefficient of atoms, enabling re-arrangement and homogenization of the growing film, also avoiding the growth of a columnar microstructure. Heating seems to lead to denser coatings (Figure $3 \mathrm{D}$ ) with a more uniform internal structure and a thin oxide layer $(<100 \mathrm{~nm})$ at the steel/coating interface.

The thermal co-evaporation method produced a Mn-Co coating with an average thickness of 1 micron, as shown in Figure 3 B. Coatings with a composition close to Mn:Co 50:50 at.\% were obtained, corresponding to $\mathrm{Mn}_{1.5} \mathrm{Co}_{1.5} \mathrm{O}_{4}$ nominal composition, as a result of metallic Mn-Co coating conversion into the spinel by sintering at $800{ }^{\circ} \mathrm{C}$ for $30 \mathrm{~min}$ in air. The $\mathrm{Mn}_{1.5} \mathrm{Co}_{1.5} \mathrm{O}_{4}$ coating adhered well to the Crofer 22 APU substrate.

Summarizing, three different methods were used to deposit 4 types of Mn-Co spinel protective coatings with a nominal composition $\mathrm{Mn}_{1.5} \mathrm{Co}_{1.5} \mathrm{O}_{4}$. Coatings differ in thickness and in microstructure, the potential differences in their protective behaviour are attractive for evaluation.

\section{Electrical conductivity tests}

Figure 4 shows the Area Specific Resistance (ASR) data recorded during the long term electrical characterization carried out at $800^{\circ} \mathrm{C}$ for $5000 \mathrm{hrs}$.

Initially, for the first $\sim 400$ hours all resistances decrease rapidly due to formation of the interface between the steel/coating and the contacting plate. Sintering of the LSM plates occurs over time and thus they increase their conductivity, more rapidly in the beginning. Additionally some creep/rearrangement of the sprayed contact layer might take place. These initial phenomena are much larger than the possible initial increase of the ASR due to the oxide growth. For the thermal co-evaporation, sputtering and a not coated sample, after this $\sim 400$ hours an increase in the ASR value starts. For the sample with a sputtered coating with a heated substrate a very rapid increase in the ASR occurred. For the EPD coated sample, increase is visible only after $\sim 2500$ hours. This difference in time might be due to possible interaction of the MCO spinel with the LSM contact layer, densification of the MCO spinel due to mechanical load etc. It has been observed previously in other coated samples measured in the same setup [61]. It shows the importance of performing long term ASR measurements, where 
for good performing samples the increase of the ASR due to chromia growth might be visible only after initial equilibration and setting effect.

ASR increase rate for the un-coated and thin spinel coated samples (not including the heated-sputtered sample) seems to be similar. Only the EPD coated sample shows visibly slower increase rate. After 5000 hours of oxidation, ASR value for the poorly performing samples is $35-45 \mathrm{~m} \Omega \mathrm{cm}^{2}$, whereas for the EPD coated samples it is $\sim 22 \mathrm{~m} \Omega \mathrm{cm}^{2}$. The rate of increase of the ASR, calculated by linear fitting of the curves between 2000-5000 hours, gives a value of $3.9 \mathrm{~m} \Omega \mathrm{cm}^{2} / 1000 \mathrm{~h}$ for thermal coevaporation, sputtering and un-coated samples and a value of $1.2 \mathrm{~m} \Omega \mathrm{cm}^{2} / 1000 \mathrm{~h}$ for the EPD coated sample. Degradation rate has been thus lowered by a factor of $3 x$. Assuming a simple linear extrapolation of the values up to 40000 hours, the EPD coated sample would have a total ASR of about $60 \mathrm{~m} \Omega \mathrm{cm}^{2}$, so below the presumed limit.

Among the coated samples, only the EPD coated ones showed a promising performance. Application of other coatings did not result in a slowing down of the ASR increase, which was relatively close to the un-coated samples, pointing at possible too low initial thickness to ensure an effective and protective action.

Post mortem characterization after 5000 hours at $800^{\circ} \mathrm{C}$

After the ASR measurement, it was possible to disassemble the whole ASR stack into separate pieces and thus examine surfaces and cross-sections of the individual coated samples. Figure 5 shows SEM images of sample surfaces after the 5000 hour experiments. Additionally, surface chemical composition has been analysed by EDS (at a low magnification of 250). White particles visible on all surfaces are leftovers from the LSM contacting plates.

Analysis of the EPD coated sample shows a porous surface similar to the initial surface. Chemical composition shows presence of $\mathrm{Mn}, \mathrm{Co}$ and a minor amount of $\mathrm{Cr}(\sim 1$ at.\%) is also detected. The ratio of $\mathrm{Mn} / \mathrm{Co}$ has increased from the initial 1:1 to 27:20 in atomic \%. Sample has therefore picked up some Mn from either the steel or more possibly from the LSM contacting plate, which is a much larger Mn reservoir.

EDS analyses of the thin coatings show that they contain a high amount of chromium. The EDS signal does not come from the steel substrate, as in this case also iron would be present. In the case of the sputtered samples, the surface of the not-heated one looks smooth whereas the surface of the sample deposited with a heated substrate shows a rough surface composed of large crystallites few micrometers in diameter. Chemical composition of both these samples is quite similar, Co is present only in $\sim 4$ at. $\%$, whereas $\mathrm{Cr}$ content is $\sim 16$ at.\%. Also the high Mn content, $\sim 20$ at. $\%$ and $~ 25$ at. $\%$, for the not heated one and heated respectively, must originate from the LSM plate. These samples seem to form a mixed Mn:Cr:Co spinel, which have relatively low electrical conductivities, comparable to 
chromia [64] and are not considered protective against chromium evaporation. The sample coated by thermal co-evaporation shows similar structure and chemical composition, also rich in $\mathrm{Cr}$ and with only $\sim 4$ at.\% Co present. The uncoated sample shows presence of $\sim 22$ at.\% $\mathrm{Cr}$ and 17.5 at.\% $\mathrm{Mn}$, originating from the surface $\mathrm{Mn}, \mathrm{Cr}$ spinel, with a possible contribution from the underlying chromia. The surface analysis of the electrically tested samples reveals that only the EPD coated spinel has blocked the outer diffusion of $\mathrm{Cr}$, though the coating was relatively porous. Other coatings have reacted heavily with $\mathrm{Cr}$ and $\mathrm{Mn}$, changing their stoichiometry considerably. Reactivity has been further studied by analysis of sample cross sections by scanning electron and transmission microscopy. Sample cross sections after the test are shown in Figure 6 A-E. On the uncoated sample oxide thickness is determined to be on average $\sim 3.5 \mu \mathrm{m}$. On top of the oxide an LSM contacting layer is still present on the surface. It must be noted, that LSM can by itself provide some corrosion protection properties, slowing oxide growth rate $[65,66]$. The interactions of the oxide scale and the contact layer used for the ASR measurement cannot be avoided $[28,67]$. As measured by the point EDS analysis, the oxide on the uncoated sample is composed of an inner $\mathrm{Cr}_{2} \mathrm{O}_{3}$ and an outer mixed $\mathrm{Mn}, \mathrm{Cr}$ spinel with the composition $\mathrm{Cr} 30$ at.\%, Mn 20 at.\% and rest O. Due to a small volume, the composition of the mixed spinel might contain some contribution from the surrounding layers. These two oxides are roughly the same in thickness.

Cross section of the EPD coated sample (Figure 6 B) shows similar microstructure to the as-prepared coating. Oxide did not grow considerably during the ASR measurement; it reached a thickness of $2.5 \mu \mathrm{m}$ on average, increasing from the initial $1.5 \mu \mathrm{m}$. Oxide thickness caused by the long term exposure on the EPD coated sample was lower than on the not coated sample, even including the initial oxide thickness caused by the high temperature sintering. The coating structure looks similar to the initial one, with a dense reaction layer next to the oxide. At some places this reaction layers seems to penetrate deeper into the porous coating than in the as-sintered state. For this sample, the oxide scale is a pure $\mathrm{Cr}_{2} \mathrm{O}_{3}$, with internal pockets containing some $\mathrm{Mn}$ and forming an internal $\mathrm{Mn}, \mathrm{Cr}$ spinel. Composition of the Mn, Co spinel is very similar to the one detected from the surface analysis. Average composition reveals 27 at.\% $\mathrm{Mn}$ and 19 at.\% Co with only a minor amount of $\mathrm{Cr}(<0.5$ at.\%). Mn is distributed uniformly throughout the coating.

Thin coatings, shown in Figures 6 C, D, E present different microstructure after the oxidation test. Due to a thick internal oxide formed by $\mathrm{Cr}_{2} \mathrm{O}_{3}$ (thickness $\sim 6-8 \mu \mathrm{m}$ ) and external oxide $\mathrm{Mn}, \mathrm{Cr}, \mathrm{Co}$, they are clearly less protective than the EPD coating. Depending on the measurement point, on all thin coated samples mixed composition $\mathrm{Mn}, \mathrm{Cr}$ spinels with $\sim 4$ at.\% of Co are detected $\left(\mathrm{Mn}_{1.5} \mathrm{Cr}_{1.5} \mathrm{O}_{4}, \mathrm{Mn}_{2} \mathrm{CrO}_{4}\right.$, $\mathrm{MnCr}_{2} \mathrm{O}_{4}$ based), also confirming the surface analysis. At many points no Co presence was detected at all, implying that a pure $\mathrm{Mn}, \mathrm{Cr}$ spinel formed. With a total thickness of the oxide $\sim 16 \mu \mathrm{m}$, these poorly conductive oxides contribute negatively to the ASR. Possible explanation about the protective 
behaviour of the EPD coatings and poor performance of the thin coatings are discussed in following paragraphs.

In order to better understand the evolution of the prepared $\mathrm{Mn}_{1.5} \mathrm{Co}_{1.5} \mathrm{O}_{4}$ coatings after the $5000 \mathrm{hrs}$ at $800^{\circ} \mathrm{C}$ and to investigate possible reactions and elemental diffusion, a more detailed analyses of these samples are reported in Figures 7, 8 and 9.

Figure 7 presents the cross section image with EDS point analyses, EDS elemental maps for $\mathrm{Cr}, \mathrm{Mn}$, $\mathrm{Co}, \mathrm{Fe}$ and $\mathrm{O}$ and a line scan of a thermal co-evaporated sample after the 5000 hours electrical measurement. Microstructures of other thin coatings after the test were similar.

Analysis of Figure $7 \mathrm{~A}$ and B, reveals that $\mathrm{Cr}$ is present both in the oxide scale and in the outer Mn,Co coating. Mn seems enriched at the outer interface of the coating, where it has been in contact with the LSM plate. This is confirmed by the line scan, in which the Mn signal increases towards the surface. This Mn enrichment influence the spinel composition, which contain less Co than in the initial state and also contain chromium, diffused from the steel/chromia. Chromium content is gradually decreasing from the chromia to the surface. From around 25 at.\% in the spinel next to chromia (point 6), to $\sim 10$ at.\% at the surface (point 2). Iron is contained only in the alloy. Some Mn also forms most likely a stable $\mathrm{MnCr}_{2} \mathrm{O}_{4}$ spinel below chromia (point 4).

All thin coatings studied in this work did not show protective behaviour. They looked quite similarly with high $\mathrm{Cr}$ content in the coating and also with a high Mn content. Possible explanation for this poor behaviour, postulated in this work, is that in the presence of a large reservoir of Mn (from the LSM plate), acting as a source of $\mathrm{Mn}$, that diffuse into the coating changing its composition and structure. Otherwise there is no other large source of Mn, and the gradient in composition towards the LSM plate supports it. Probably, small thickness and very small particle size and not well defined grains reacted strongly with the Mn, destabilizing its structure and allowed for the diffusion of Cr. The protective spinel became mostly a mixed $\mathrm{Mn}, \mathrm{Cr}$, Co spinel, which loses its good electrical conductivity. This seems to be confirmed by other studies performed on $\mathrm{Mn}, \mathrm{Co}$, Cr spinels $[14,64,68]$.

Figure 8 presents cross section image with EDS point analyses, EDS elemental maps for $\mathrm{Cr}, \mathrm{Mn}, \mathrm{Co}$, $\mathrm{Fe}$ and $\mathrm{O}$ and a linescan of the electrophoretically deposited sample after 5000 hours electrical measurement. In this case $\mathrm{Mn}$ is also enriched, however to a smaller extent than in the thin coatings. This was also visible in the EDS analysis of the surface of the exposed samples, presented in Figure 5 A. The average ratio of $\mathrm{Mn}: \mathrm{Co}$ is $\sim 27: 20$ at. $\%$. This has not led to any visible microstructural changes, as the density of the exposed samples seem similar to the as-sintered sample. Only a minor amount of $\mathrm{Cr}$ is found in the coating. In the inner part of the dense reaction layer between the coating and the chromia the $\mathrm{Cr}$ content is $\sim 1.5$ at.\%, whereas in the rest of the coating it drops to below 1 at.\% on average (within a detection limit of EDS, though a small peak was definitely detected). Also some internal $\mathrm{MnCr}_{2} \mathrm{O}_{4}$ spinel exist below the chromia. There are some voids visible below chromia, that are 
believed to be the result from $\mathrm{Cr}$ and $\mathrm{Mn}$ elements outward diffusion or caused by the mechanical polishing of the sample.

In the case of the EPD prepared spinel coating, it provided a protective behaviour for the alloy over the testing period. This has also been observed by other authors [31,67]. Contact with a Mn source did not lead to a negative spinel compositional change. From the beginning, spinel had a well formed relatively large particles that underwent sintering in air, and then they picked up Mn from the LSM during the long term oxidation exposure. Thickness of the EPD coating is much higher than for the thin coatings, so the smaller amount of $\mathrm{Mn}$ increase still means a relatively large flux of the total $\mathrm{Mn}$ diffused, possibly comparable with the total amount of Mn diffused into the thinner coatings. Reaction layer that formed during the sintering protected the rest of the coating from an outward Cr diffusion. It also caused slight oxide growth over this 5000 hour period, possibly due to limiting oxygen diffusion. In order to study possible chromium diffusion in more details, advanced transmission electron microscopy evaluation has been performed on this sample.

A TEM image, showing the FIB lamella of the Crofer 22 APU-oxide scale- $\mathrm{Mn}_{1.5} \mathrm{Co}_{1.5} \mathrm{O}_{4}$ coating together with the STEM-EDS maps for $\mathrm{Co}, \mathrm{Cr}, \mathrm{Mn}, \mathrm{Fe}$ and $\mathrm{O}$ are reported in Figure 9. The $\mathrm{Cr}$ distribution map across the $\mathrm{Mn}_{1.5} \mathrm{Co}_{1.5} \mathrm{O}_{4}$-Crofer $22 \mathrm{APU}$ cross section showed that the coating essentially blocked the outward diffusion of $\mathrm{Cr}$ after the thermal ageing at $800^{\circ} \mathrm{C}$ for 5000 hours. The oxide scale is rich in $\mathrm{Mn}$ in the inner layer $(\sim 0.5 \mu \mathrm{m})$, while it is mainly composed of chromia in the outer part; this observation is confirmed by the EDS analyses reported in Table 1, in particular by EDS analyses in areas 2 and 3, respectively. A large pore is visible at the Crofer 22 APU substrate/oxide scale interface; these kind of voids and porosities (as previously shown in Figure 8) may result from $\mathrm{Cr}$ and $\mathrm{Mn}$ and also $\mathrm{Fe}$, elements outward diffusion or from the preparation of the FIB lamella. EDS maps confirms that some $\mathrm{Fe}$, together with $\mathrm{Cr}$ and $\mathrm{Mn}$, is present in the inner part of the oxide scale. Composition of Area 2 is close to the expected $\mathrm{MnCr}_{2} \mathrm{O}_{4}$ composition for the internal spinel.

The presence of $\sim 7$ at.\% Cr, together with a higher Co:Mn $>1$ are detected by EDS in areas 4 and 10, which are in the spinel coating at the boundary area with the oxide scale. The ratio $(\mathrm{Co}+\mathrm{Cr}) / \mathrm{Mn}$ is $\sim 2$. It seems that a small diffusion of $\mathrm{Cr}$ into the reaction layer stabilizes the cubic phase of the spinel next to the chromia. In the spinel regions rich in Mn (tetragonal spinel) and rich in Co (cubic spinel) are clearly visible, as discussed earlier on the spinel composition at room temperature.

The formation of a reaction layer has been previously shown by other studies [14,69]. This reaction layer could be constituted by a mixed spinel $(\mathrm{Mn}, \mathrm{Co}, \mathrm{Cr})_{3} \mathrm{O}_{4}$ and was due to the inter-diffusion of elements from $(\mathrm{Cr})$ and toward the steel (especially $\mathrm{O}$ and $\mathrm{Co}$ ). These compounds are undesirable because of their low electrical conductivity [12]; however in the present study the thickness of this 
layer is very low $(\sim 0.5 \mu \mathrm{m})$, especially considering the long duration of the ASR test. Magdefrau et al detected a similar layer with a thickness around $4 \mu \mathrm{m}$ after an exposure for $1000 \mathrm{~h}$ at $800^{\circ} \mathrm{C} \mathrm{[69].}$

In addition to STEM-EDS, selected area electron diffraction (SAED) patterns were analysed in selected areas (patterns not shown here) with help of JEMS software. The performed analysis suggests the presence of mixture of $\mathrm{Mn}_{2} \mathrm{CoO}_{4}$ and $\mathrm{MnCo}_{2} \mathrm{O}_{4}$ phases in the investigated areas. Nevertheless it should be noted that $\mathrm{MnCoCrO}_{4}$ can also co-exist. All those phases have a very similar crystallographic structure: the same space group number $(\mathrm{Fd}-3 \mathrm{~m})$ and similar lattice parameters $(\mathrm{a}=$ 8.4 and $8.3 \mathrm{~nm}$ ) [70]. As a result, diffraction patterns from those phases look the same. EDS analysis of some of the investigated areas showed small $\mathrm{Cr}$ enrichment, so it is possible that one of the phases that exists in the areas 4 and 10 will be $\mathrm{MnCoCrO}_{4}$. Furthermore, these areas are rich in Co and this behaviour can be explained by an inward diffusion of Co towards the chromia layer; this "reaction layer" seems to have a positive effect in reducing $\mathrm{Cr}$ volatilization and diffusion to the rest of the coating. The remaining areas $(6,7,8$ and 9) belong to the Mn-Co spinel. Different bright and dark areas correspond to Co and $\mathrm{Mn}$ rich areas, respectively; this observation is confirmed by the SAED analyses (collected in areas 7 and 8, respectively), thus confirming the presence of the $\mathrm{MnCo}_{2} \mathrm{O}_{4}$ and $\mathrm{Mn}_{2} \mathrm{CoO}_{4}$ phases. From analysis of the elemental maps in Figure 9, it seems that the $\mathrm{Mn}_{2} \mathrm{CoO}_{4}$ spinel phase is represented to a higher extent than $\mathrm{MnCo}_{2} \mathrm{O}_{4}$ spinel. That observation would be in-line with the Figure 8, where on a more macroscopic scale, Mn enrichment has been noticed, which led to formation of more $\mathrm{Mn}_{2} \mathrm{CoO}_{4}$ phase than initially.

EDS mappings of the EPD prepared $\mathrm{Mn}_{1.5} \mathrm{Co}_{1.5} \mathrm{O}_{4}$-Crofer $22 \mathrm{APU}$, taken both by SEM and TEM on the cross sections after the 5000 hours test, confirmed that the $\sim 15 \mu \mathrm{m}$ thick $\mathrm{Mn}_{1.5} \mathrm{Co}_{1.5} \mathrm{O}_{4}$ protective coating effectively prevented the outward migration of $\mathrm{Cr}$, thus proving the $\mathrm{Cr}$ retention efficiency of the spinel coating. The coating produced by EPD reduced the oxide scale growth rate and blocked outward diffusion of $\mathrm{Cr}$ from the oxide scale that grew between the coating and the steel substrate during the $5000 \mathrm{hrs}$ long-term tests. As a technological relevance, the EPD technique can be used to coat shaped substrates, thus offering a solution for coating real interconnects for practical applications. On the other hand, the thin coatings obtained by thermal co-evaporation and RF sputtering techniques were found to react heavily with Mn from the LSM contacting plate and $\mathrm{Cr}$ from the alloy/chromia. Even if initially dense coatings could be obtained by these techniques, their effectiveness in $\mathrm{Cr}$ retention capability and limiting the growth of the oxide scale, with a consequent influence on the ASR values, was found to be limited. Furthermore, the intrinsic nature of the sputtering process, where sputtered ions randomly reach the surface of the substrate, can lead to inhomogeneous thickness of the coating. This will be especially important if shaped (e.g. real interconnect) surfaces have to be coated. During the sputtering deposition, shadowing effects can potentially have a significant influence on the coating deposition on the sidewalls and on the bottom of a channel. The geometric effect of the 
interconnect substrate can play a critical role also for the thermal co-evaporation technique, where the coating in terms of homogeneity for complex surfaces should be improved for example by rotating the substrate during deposition.

Discussion on chemical reactivity of the coatings with LSM

It has been noticed in this work, that the presence of the external Mn source (LSM contact plate in our case) can have an important effect on the behaviour of the coatings. The issue of Mn diffusion leading to compositional change of the coating can possibly precedent loose of the protective properties (for thin films) and can have a profound effect on the long term resistance of coatings in direct contact with the contacting elements (containing Mn). Moreover, as has been shown in this work, also thick coatings change their chemical composition due to Mn pick up. It seems however, that larger volume of the thick spinel coating tolerate it well in this 5000 hours exposure. Possible Mn diffusion from the external sources into the coating during high temperature exposure constitute a very important difference between measuring the corrosion properties of the isolated coated samples (e.g. pure thermogravimetric experiments) and samples in contact with reacting external layers. One can also possibly measure electrical conductivity with the use of less reactive layers, e.g. platinum, but always some interaction will occur. Studies of these effects are important in terms of real components for stacks. This is evidenced in this study and should be considered when designing and evaluating ceramic protective coatings.

Schematics of a possible reactivity of the thin and thick coating are shown in Figure 10. In the case of the coatings not in contact with an external Mn source (Figures $10 \mathrm{~A}$ and $\mathrm{C}$ ), the coating does not change its chemical composition considerably during the exposure. Small diffusion of $\mathrm{Cr}$ from chromia can occur and some further evolution of the reaction layer is also expected [61,63]. For thin films, also mainly growth of chromia scale is expected [58]. Behaviour of coatings changes in the presence of an external Mn source, as shown schematically in Figures $10 \mathrm{~B}$ and D. For the thick coating, some Mn diffuses into the porous spinel coating. In addition, chromia growth occurs, but $\mathrm{Cr}$ is mainly contained in the chromia and to a small extent in the reaction layer $(\sim 0.5 \mu \mathrm{m})$ and in the coating $(<1$ at.\%). Based on TEM-EDS/SAED, the dense reaction layers seems to be a cubic Co rich spinel and $\mathrm{Cr}$ content in the porous coating is very low $(<0.5$ at.\%).

For the thin coatings, extensive diffusion of $\mathrm{Cr}$ from the alloy/chromia into the initial coating occurs, in addition to Mn diffusion from the LSM plate. A thick $\left(\sim 16 \mu \mathrm{m}\right.$ after $5000 \mathrm{~h}$ at $\left.800^{\circ} \mathrm{C}\right)$ mixed $\mathrm{Mn}, \mathrm{Cr}$,Co spinel forms. It has been highly "diluted" by diffusing $\mathrm{Mn}$ and $\mathrm{Cr}$, so that the Co content is very low ( 4 at.\% instead of the initial $\sim 20$ at.\%). Both the low initial thickness of the thin coatings (small volume) and small grain size due to low temperature preparation (faster diffusion through grain boundaries) might play a role in rapid degradation of the spinel. 


\section{Conclusions}

Out of the three Mn-Co spinel coatings compared in this study, the one deposited by EPD presented the best protection against $\mathrm{Cr}$ diffusion, contributing to the lowest ASR value and lowest increase rate. After 5000 hours of oxidation, ASR values for the RF sputtering and thermal evaporation coated samples were 35-45 $\mathrm{m} \Omega \mathrm{cm}^{2}$, whereas for the EPD coated samples ASR reached $22 \mathrm{~m} \Omega \mathrm{cm}^{2}$. Concerning the degradation rate, it was found to be lowered by a factor of $3 \mathrm{x}$ in the case of EPD coated samples.

SEM and TEM post mortem analyses confirmed that the spinel coating deposited by EPD reduced the oxide scale growth rate and blocked the outward diffusion of $\mathrm{Cr}$ from the oxide scale that grew between the coating and the steel substrate during the $5000 \mathrm{hrs}$ tests. Even if dense coatings were obtained by RF sputtering and thermal evaporation techniques, their effectiveness in Cr retention capability and hindering the growth of the oxide scale, with a consequent influence on the ASR values, were found to be limited. The loss of the protective properties for the thin films was possible due to inward Mn diffusion (enhanced by the small thickness as well as by the submicron grain size) and a consequent significant compositional modification, leading to formation of a mixed $\mathrm{Mn}, \mathrm{Cr}$, Co spinel and a consequent increase of electrical resistance.

\section{Acknowledgements}

ESTEEM and KMM-VIN fellowships ( $6^{\text {th }}$ call $)$ granted to Mr. Antonio Gianfranco Sabato are kindly acknowledged. DTU Energy acknowledges support from Energinet.dk through the ForskEl project number 2015-1-12276 "Towards solid oxide electrolysis plants in 2020". 


\section{References}

[1] T. Van Gestel, D. Sebold, H.P. Buchkremer, Processing of 8YSZ and CGO thin film electrolyte layers for intermediate- and low-temperature SOFCs, J. Eur. Ceram. Soc. 35 (2015) 15051515. doi:10.1016/j.jeurceramsoc.2014.11.017.

[2] E. Ivers-Tiffée, A. Weber, D. Herbstritt, Materials and technologies for SOFC-components, J. Eur. Ceram. Soc. 21 (2001) 1805-1811. doi:10.1016/S0955-2219(01)00120-0.

[3] A. Chrzan, J. Karczewski, M. Gazda, D. Szymczewska, P. Jasinski, La0.6Sr0.4Co0.2Fe0.8O3$\delta$ oxygen electrodes for solid oxide cells prepared by polymer precursor and nitrates solution infiltration into gadolinium doped ceria backbone, J. Eur. Ceram. Soc. 37 (2017) 3559-3564. doi:10.1016/j.jeurceramsoc.2017.04.032.

[4] N.H. Menzler, F. Tietz, S. Uhlenbruck, H.P. Buchkremer, D. Stöver, Materials and manufacturing technologies for solid oxide fuel cells, J. Mater. Sci. 45 (2010) 3109-3135. doi:10.1007/s10853-010-4279-9.

[5] F. Smeacetto, M. Salvo, M. Ferraris, V. Casalegno, P. Asinari, A. Chrysanthou, Characterization and performance of glass-ceramic sealant to join metallic interconnects to YSZ and anode-supported-electrolyte in planar SOFCs, J. Eur. Ceram. Soc. 28 (2008) 2521-2527. doi:10.1016/j.jeurceramsoc.2008.03.035.

[6] S.M. Jamil, M.H.D. Othman, M.A. Rahman, J. Jaafar, A.F. Ismail, K. Li, Recent fabrication techniques for micro-tubular solid oxide fuel cell support: A review, J. Eur. Ceram. Soc. 35 (2015) 122. doi:10.1016/j.jeurceramsoc.2014.08.034.

[7] J. Wu, X. Liu, Recent Development of SOFC Metallic Interconnect, J. Mater. Sci. Technol. 26 (2010) 293-305. doi:10.1016/S1005-0302(10)60049-7.

[8] T. Horita, M. Yoshinaga, H. Kishimoto, K. Yamaji, M.E. Brito, Y. Xiong, et al., Effects of Thermal Cycling on the Formation of Oxide Scale of Fe-Cr Alloy Interconnects for Solid Oxide Fuel Cells, Int. J. Appl. Ceram. Technol. 8 (2011) 1374-1381. doi:10.1111/j.1744-7402.2010.02600.x.

[9] X. Sun, W.N. Liu, E. Stephens, M.A. Khaleel, Determination of interfacial adhesion strength between oxide scale and substrate for metallic SOFC interconnects, J. Power Sources. 176 (2008) 167-174. doi:10.1016/j.jpowsour.2007.10.027.

[10] W.N. Liu, X. Sun, E. Stephens, M. Khaleel, Effect of substrate thickness on oxide scale spallation for solid oxide fuel cells, Corros. Sci. 53 (2011) 2406-2412. doi:10.1016/j.corsci.2011.03.025.

[11] C. Gindorf, L. Singheiser, K. Hilpert, Vaporisation of chromia in humid air, J. Phys. Chem. Solids. 66 (2005) 384-387. doi:10.1016/j.jpcs.2004.06.092.

[12] R. Trebbels, T. Markus, L. Singheiser, Investigation of Chromium Vaporization From Interconnector Steels With Spinel Coatings, J. Fuel Cell Sci. Technol. 7 (2010) 11013. doi:10.1115/1.3117607. 
[13] M. Stanislowski, J. Froitzheim, L. Niewolak, W.J. Quadakkers, K. Hilpert, T. Markus, et al., Reduction of chromium vaporization from SOFC interconnectors by highly effective coatings, J. Power Sources. 164 (2007) 578-589. doi:10.1016/j.jpowsour.2006.08.013.

[14] K. Wang, Y. Liu, J.W. Fergus, Interactions Between SOFC Interconnect Coating Materials and Chromia, J. Am. Ceram. Soc. 94 (2011) 4490-4495. doi:10.1111/j.1551-2916.2011.04749.x.

[15] S. Molin, M. Chen, P.V. Hendriksen, Oxidation study of coated Crofer 22 APU steel in dry oxygen, J. Power Sources. 251 (2013) 488-495. doi:10.1016/j.jpowsour.2013.09.100.

[16] M. Palcut, L. Mikkelsen, K. Neufeld, M. Chen, R. Knibbe, P.V. Hendriksen, Efficient dual layer interconnect coating for high temperature electrochemical devices, Int. J. Hydrogen Energy. 37 (2012) 14501-14510. doi:10.1016/j.ijhydene.2012.07.038.

[17] D.N. Boccaccini, O. Sevecek, H.L. Frandsen, I. Dlouhy, S. Molin, B. Charlas, et al., Determination of the bonding strength in solid oxide fuel cells' interfaces by Schwickerath crack initiation test, J. Eur. Ceram. Soc. 37 (2016) 3565-3578. doi:10.1016/j.jeurceramsoc.2017.04.018.

[18] Z. Yang, G.-G. Xia, X.-H. Li, J.W. Stevenson, (Mn,Co)3O4 spinel coatings on ferritic stainless steels for SOFC interconnect applications, Int. J. Hydrogen Energy. 32 (2007) 3648-3654. doi:10.1016/j.ijhydene.2006.08.048.

[19] E. Stefan, G. Tsekouras, J.T.S. Irvine, Development and Performance of MnFeCrO 4 -Based Electrodes for Solid Oxide Fuel Cells, Adv. Energy Mater. 3 (2013) 1454-1462. doi:10.1002/aenm.201300361.

[20] A. Gaur, V.M. Sglavo, Flash-sintering of $\mathrm{MnCo} 2 \mathrm{O} 4$ and its relation to phase stability, J. Eur. Ceram. Soc. 34 (2014) 2391-2400. doi:10.1016/j.jeurceramsoc.2014.02.012.

[21] J. Wu, Y. Jiang, C. Johnson, X. Liu, DC electrodeposition of Mn-Co alloys on stainless steels for SOFC interconnect application, J. Power Sources. $177 \quad$ (2008) 376-385. doi:10.1016/j.jpowsour.2007.11.075.

[22] R. Pinto, M.J. Carmezim, M.F. Montemor, Electrodeposition and isothermal aging of Co and Mn layers on stainless steel for interconnectors: Initial stages of spinel phase formation, J. Power Sources. (2014). http://www.sciencedirect.com/science/article/pii/S0378775314000433 (accessed January 21, 2014).

[23] S. Apelt, Y. Zhang, J.H. Zhu, C. Leyens, Electrodeposition of Co-Mn3O4 composite coatings, Surf. Coatings Technol. 280 (2015) 208-215. doi:10.1016/j.surfcoat.2015.09.011.

[24] V.I. Gorokhovsky, P.E. Gannon, M.C. Deibert, R.J. Smith, A. Kayani, M. Kopczyk, et al., Deposition and Evaluation of Protective PVD Coatings on Ferritic Stainless Steel SOFC Interconnects, J. Electrochem. Soc. 153 (2006) A1886. doi:10.1149/1.2266244.

[25] C.C. Mardare, M. Spiegel, A. Savan, A. Ludwig, Thermally Oxidized Mn-Co Thin Films as Protective Coatings for SOFC Interconnects, J. Electrochem. Soc. 156 (2009) B1431. doi:10.1149/1.3240597. 
[26] C.C. Mardare, H. Asteman, M. Spiegel, A. Savan, A. Ludwig, Investigation of thermally oxidised Mn-Co thin films for application in SOFC metallic interconnects, Appl. Surf. Sci. 255 (2008) 1850-1859. doi:10.1016/j.apsusc.2008.06.052.

[27] O. Thomann, M. Pihlatie, M. Rautanen, O. Himanen, J. Lagerbom, M. Mäkinen, et al., Development and Application of HVOF Sprayed Spinel Protective Coating for SOFC Interconnects, J. Therm. Spray Technol. 22 (2013) 631-639. doi:10.1007/s11666-012-9880-9.

[28] S.J. Han, Z. Pala, S. Sampath, Plasma sprayed manganese-cobalt spinel coatings: Process sensitivity on phase, electrical and protective performance, J. Power Sources. 304 (2016) 234-243. doi:10.1016/j.jpowsour.2015.11.040.

[29] J. Puranen, M. Pihlatie, J. Lagerbom, G. Bolelli, J. Laakso, L. Hyvärinen, et al., Post-mortem evaluation of oxidized atmospheric plasma sprayed $\mathrm{Mn}-\mathrm{Co}-\mathrm{Fe}$ oxide spinel coatings on SOFC interconnectors, Int. J. Hydrogen Energy. $39 \quad$ (2014) 17284-17294. doi:10.1016/j.ijhydene.2014.08.105.

[30] J.W. Fergus, Metallic interconnects for solid oxide fuel cells, Mater. Sci. Eng. A. 397 (2005) $271-283$.

[31] J.W. Stevenson, Z.G. Yang, G.G. Xia, Z. Nie, J.D. Templeton, Long-term oxidation behavior of spinel-coated ferritic stainless steel for solid oxide fuel cell interconnect applications, J. Power Sources. 231 (2013) 256-263. doi:10.1016/j.jpowsour.2013.01.033.

[32] S.R. Akanda, N.J. Kidner, M.E. Walter, Spinel coatings on metallic interconnects: Effect of reduction heat treatment on performance, Surf. Coatings Technol. 253 (2014) 255-260. doi:10.1016/j.surfcoat.2014.05.049.

[33] P. Piccardo, P. Gannon, S. Chevalier, M. Viviani, A. Barbucci, G. Caboche, et al., ASR evaluation of different kinds of coatings on a ferritic stainless steel as SOFC interconnects, Surf. Coatings Technol. 202 (2007) 1221-1225. doi:10.1016/j.surfcoat.2007.07.096.

[34] J.-J. Choi, J. Ryu, B.-D. Hahn, W.-H. Yoon, B.-K. Lee, D.-S. Park, Dense spinel MnCo2O4 film coating by aerosol deposition on ferritic steel alloy for protection of chromic evaporation and low-conductivity scale formation, J. Mater. Sci. 44 (2009) 843-848. doi:10.1007/s10853-008-3132-x.

[35] A. Masi, M. Bellusci, S.J. McPhail, F. Padella, P. Reale, J.-E. Hong, et al., Cu-Mn-Co oxides as protective materials in SOFC technology: The effect of chemical composition on mechanochemical synthesis, sintering behaviour, thermal expansion and electrical conductivity, J. Eur. Ceram. Soc. 37 (2017) 661-669. doi:10.1016/j.jeurceramsoc.2016.09.025.

[36] T. Brylewski, A. Kruk, M. Bobruk, A. Adamczyk, J. Partyka, P. Rutkowski, Structure and electrical properties of $\mathrm{Cu}$-doped $\mathrm{Mn}-\mathrm{Co}-\mathrm{O}$ spinel prepared via soft chemistry and its application in intermediate-temperature solid oxide fuel cell interconnects, J. Power Sources. 333 (2016) 145-155. doi:10.1016/j.jpowsour.2016.09.136. 
[37] N. El Horr, S. Guillemet-Fritsch, A. Rousset, H. Bordeneuve, C. Tenailleau, Microstructure of single-phase cobalt and manganese oxide spinel $\mathrm{Mn} 3-\mathrm{xCoxO} 4$ ceramics, J. Eur. Ceram. Soc. 34 (2014) 317-326. doi:10.1016/j.jeurceramsoc.2013.08.010.

[38] H. Zhang, Z. Zhan, X. Liu, Electrophoretic deposition of (Mn,Co)3O4 spinel coating for solid oxide fuel cell interconnects, J. Power Sources. $196 \quad$ (2011) 8041-8047. doi:10.1016/j.jpowsour.2011.05.053.

[39] Z. Yang, G. Xia, J.W. Stevenson, Mn[sub 1.5]Co[sub 1.5]O[sub 4] Spinel Protection Layers on Ferritic Stainless Steels for SOFC Interconnect Applications, Electrochem. Solid-State Lett. 8 (2005) A168-A170. doi:10.1149/1.1854122.

[40] Y. Fang, C. Wu, X. Duan, S. Wang, Y. Chen, High-temperature oxidation process analysis of MnCo2O4 coating on Fe-21Cr alloy, Int. J. Hydrogen Energy. 36 (2011) 5611-5616. doi:10.1016/j.ijhydene.2011.01.130.

[41] N.N.V. Gavrilov, V.V.V. Ivanov, A.S.A. Kamenetskikh, A.A.V. Nikonov, Investigations of $\mathrm{Mn}-\mathrm{Co}-\mathrm{O}$ and $\mathrm{Mn}-\mathrm{Co}-\mathrm{Y}-\mathrm{O}$ coatings deposited by the magnetron sputtering on ferritic stainless steels, Surf. Coatings Technol. 206 (2011) 1252-1258. doi:10.1016/j.surfcoat.2011.08.036.

[42] L. Zhang, R. Lan, P.I. Cowin, S. Tao, Fabrication of solid oxide fuel cell based on doped ceria electrolyte by one-step sintering at $800^{\circ} \mathrm{C}$, Solid State Ionics. 203 (2011) 47-51. doi:10.1016/j.ssi.2011.09.015.

[43] A. Gondolini, E. Mercadelli, A. Sangiorgi, A. Sanson, Integration of Ni-GDC layer on a NiCrAl metal foam for SOFC application, J. Eur. Ceram. Soc. 37 (2017) 1023-1030. doi:10.1016/j.jeurceramsoc.2016.09.021.

[44] T. Hosomi, M. Matsuda, M. Miyake, Electrophoretic deposition for fabrication of YSZ electrolyte film on non-conducting porous NiO-YSZ composite substrate for intermediate temperature SOFC, J. Eur. Ceram. Soc. 27 (2007) 173-178. doi:10.1016/j.jeurceramsoc.2006.04.175.

[45] R. Zehbe, C. Mochales, D. Radzik, W.D. Müller, C. Fleck, Electrophoretic deposition of multilayered (cubic and tetragonal stabilized) zirconia ceramics for adapted crack deflection, J. Eur. Ceram. Soc. 36 (2016) 357-364. doi:10.1016/j.jeurceramsoc.2015.08.022.

[46] L. Besra, M. Liu, A review on fundamentals and applications of electrophoretic deposition (EPD), Prog. Mater. Sci. 52 (2007) 1-61. doi:10.1016/j.pmatsci.2006.07.001.

[47] I. Corni, M.P. Ryan, A.R. Boccaccini, Electrophoretic deposition: From traditional ceramics to nanotechnology, J. Eur. Ceram. Soc. 28 (2008) 1353-1367. doi:10.1016/j.jeurceramsoc.2007.12.011.

[48] P. Sarkar, P.S. Nicholson, Electrophoretic Deposition (EPD): Mechanisms, Kinetics, and Application to Ceramics, J. Am. Ceram. Soc. 79 (1996) 1987-2002. doi:10.1111/j.11512916.1996.tb08929.x.

[49] A.R. Boccaccini, C. Peters, J.A. Roether, D. Eifler, S.K. Misra, E.J. Minay, Electrophoretic deposition of polyetheretherketone (PEEK) and PEEK/Bioglass ${ }^{\circledR}$ coatings on NiTi shape memory alloy wires, J. Mater. Sci. 41 (2006) 8152-8159. doi:10.1007/s10853-006-0556-Z. 
[50] D. Szymczewska, S. Molin, V. Venkatachalam, M. Chen, P. Jasinski, P.V. Hendriksen, Assesment of (Mn,Co)3O4 powders for possible coating material for SOFC/SOEC interconnects, IOP Conf. Ser. Mater. Sci. Eng. 104 (2016) 12017. doi:10.1088/1757-899X/104/1/012017.

[51] A.R. Boccaccini, F. Chicatun, J. Cho, O. Bretcanu, J.A. Roether, S. Novak, et al., Carbon Nanotube Coatings on Bioglass-Based Tissue Engineering Scaffolds, Adv. Funct. Mater. 17 (2007) 2815-2822. doi:10.1002/adfm.200600887.

[52] Y. Zhang, A. Javed, M. Zhou, S. Liang, P. Xiao, Fabrication of Mn-Co Spinel Coatings on Crofer 22 APU Stainless Steel by Electrophoretic Deposition for Interconnect Applications in Solid Oxide Fuel Cells, Int. J. Appl. Ceram. Technol. 11 (2014) 332-341. doi:10.1111/ijac.12013.

[53] W. Wei, W. Chen, D.G. Ivey, Oxidation resistance and electrical properties of anodically electrodeposited Mn-Co oxide coatings for solid oxide fuel cell interconnect applications, J. Power Sources. 186 (2009) 428-434. doi:10.1016/j.jpowsour.2008.09.114.

[54] M. Mirzaei, A. Simchi, M.A. Faghihi-Sani, A. Yazdanyar, Electrophoretic deposition and sintering of a nanostructured manganese-cobalt spinel coating for solid oxide fuel cell interconnects, Ceram. Int. 42 (2016) 6648-6656. doi:10.1016/j.ceramint.2016.01.012.

[55] H. Abdoli, P. Alizadeh, Electrophoretic deposition of (Mn,Co)3O4 spinel nano powder on SOFC metallic interconnects, Mater. Lett. 80 (2012) 53-55. doi:10.1016/j.matlet.2012.04.072.

[56] J. YOO, S.-K. Woo, J.H. YU, S. LEE, G.W. PARK, La0.8Sr0.2MnO3 and (Mn1.5Co1.5)O4 double layer coated by electrophoretic deposition on Crofer22 APU for SOEC interconnect applications, Int. J. Hydrogen Energy. 34 (2009) 1542-1547. doi:10.1016/j.ijhydene.2008.12.005.

[57] F. Smeacetto, A. De Miranda, S. Cabanas Polo, S. Molin, D. Boccaccini, M. Salvo, et al., Electrophoretic Deposition of Mn1.5 Co1.5 O4 on Metallic Interconnect and Interaction with Glassceramic Sealant for Solid Oxide Fuel Cells Application, J. Power Sources. 280 (2015) 379-386. doi:10.1016/j.jpowsour.2015.01.120.

[58] L.C. Ajitdoss, F. Smeacetto, M. Bindi, D. Beretta, M. Salvo, M. Ferraris, Mn1.5Co1.5O4 protective coating on Crofer22APU produced by thermal co-evaporation for SOFCs, Mater. Lett. 95 (2013) 82-85. doi:10.1016/j.matlet.2012.12.079.

[59] H. Zhang, J. Wu, X. Liu, A. Baker, Studies on elements diffusion of Mn/Co coated ferritic stainless steel for solid oxide fuel cell interconnects application, Int. J. Hydrogen Energy. 38 (2013) 5075-5083. doi:10.1016/j.ijhydene.2013.02.026.

[60] Q. Fu, F. Tietz, D. Sebold, E. Wessel, H.-P. Buchkremer, Magnetron-sputtered cobalt-based protective coatings on ferritic steels for solid oxide fuel cell interconnect applications, Corros. Sci. 54 (2012) 68-76. doi:10.1016/j.corsci.2011.08.051.

[61] S. Molin, P. Jasinski, L. Mikkelsen, W. Zhang, M. Chen, P.V. Hendriksen, Low temperature processed $\mathrm{MnCo} 2 \mathrm{O} 4$ and $\mathrm{MnCo} 1.8 \mathrm{Fe} 0.2 \mathrm{O} 4$ as effective protective coatings for solid oxide fuel cell interconnects at $750{ }^{\circ} \mathrm{C}$, J. Power Sources. 336 (2016) 408-418. doi:10.1016/j.jpowsour.2016.11.011. 
[62] T. Brylewski, W. Kucza, A. Adamczyk, A. Kruk, M. Stygar, M. Bobruk, et al., Microstructure and electrical properties of $\mathrm{Mn} 1+\mathrm{xCo} 2-\mathrm{xO} 4(0 \leq \mathrm{x} \leq 1.5)$ spinels synthesized using EDTA-gel processes, Ceram. Int. 40 (2014) 13873-13882. doi:10.1016/j.ceramint.2014.05.106.

[63] B. Talic, H. Falk-Windisch, V. Venkatachalam, P.V. Hendriksen, K. Wiik, H.L. Lein, Effect of coating density on oxidation resistance and $\mathrm{Cr}$ vaporization from solid oxide fuel cell interconnects, J. Power Sources. 354 (2017) 57-67. doi:10.1016/j.jpowsour.2017.04.023.

[64] Y. Liu, J.W. Fergus, C. Dela Cruz, Electrical Properties, Cation Distributions, and Thermal Expansion of Manganese Cobalt Chromite Spinel Oxides, J. Am. Ceram. Soc. 96 (2013) 1841-1846. doi:10.1111/jace.12254.

[65] M. Palcut, L. Mikkelsen, K. Neufeld, M. Chen, R. Knibbe, P.V. Hendriksen, Improved oxidation resistance of ferritic steels with LSM coating for high temperature electrochemical applications, Int. J. Hydrogen Energy. 37 (2012) 8087-8094. doi:10.1016/j.ijhydene.2011.11.138.

[66] J. Malzbender, P. Batfalsky, R. Vaßen, V. Shemet, F. Tietz, Component interactions after long-term operation of an SOFC stack with LSM cathode, J. Power Sources. 201 (2012) 196-203. doi:10.1016/j.jpowsour.2011.10.117.

[67] J.G. Grolig, P. Alnegren, J. Froitzheim, J.-E. Svensson, Copper Iron Conversion Coating for Solid Oxide Fuel Cell Interconnects, J. Power Sources. 297 (2015) 534-539. doi:10.1016/j.jpowsour.2015.06.139.

[68] Y. Xu, Z. Wen, S. Wang, T. Wen, Cu doped Mn-Co spinel protective coating on ferritic stainless steels for SOFC interconnect applications, Solid State Ionics. 192 (2011) 561-564. doi:10.1016/j.ssi.2010.05.052.

[69] N.J. Magdefrau, L. Chen, E.Y. Sun, J. Yamanis, M. Aindow, Formation of spinel reaction layers in manganese cobaltite - coated Crofer22 APU for solid oxide fuel cell interconnects, J. Power Sources. 227 (2013) 318-326. doi:10.1016/j.jpowsour.2012.07.091.

[70] M.V.F. Schlupp, J.W. Kim, A. Brevet, C. Rado, K. Couturier, U.F. Vogt, et al., Avoiding chromium transport from stainless steel interconnects into contact layers and oxygen electrodes in intermediate temperature solid oxide electrolysis stacks, J. Power Sources. 270 (2014) 587-593. doi:10.1016/j.jpowsour.2014.07.094. 


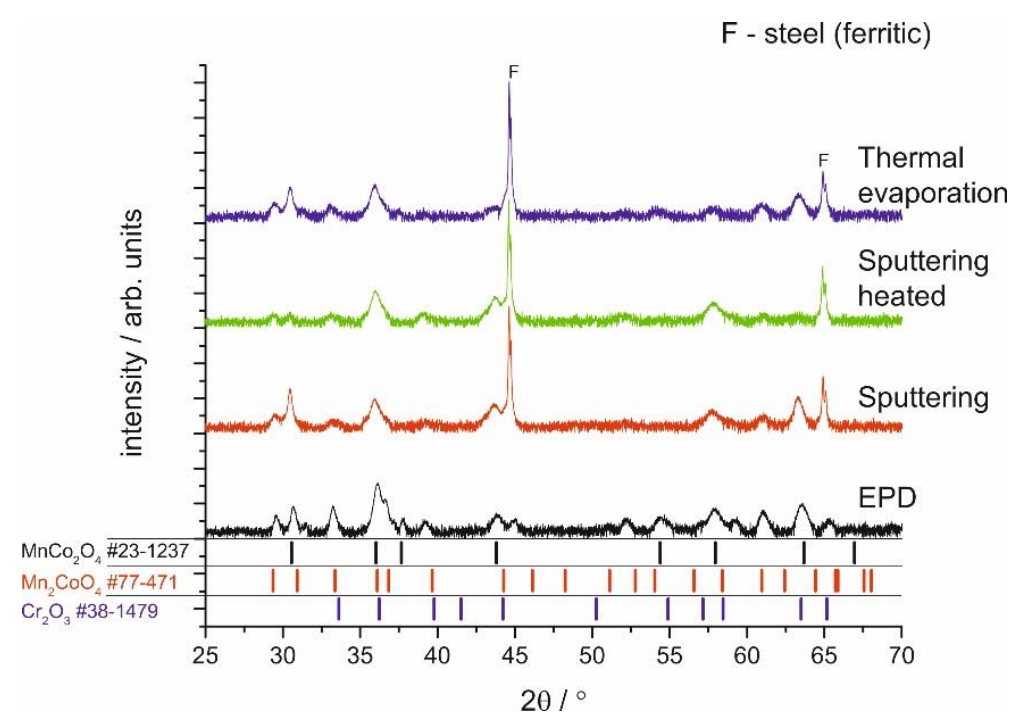

Figure 1. XRD patterns of the as-coated alloys.

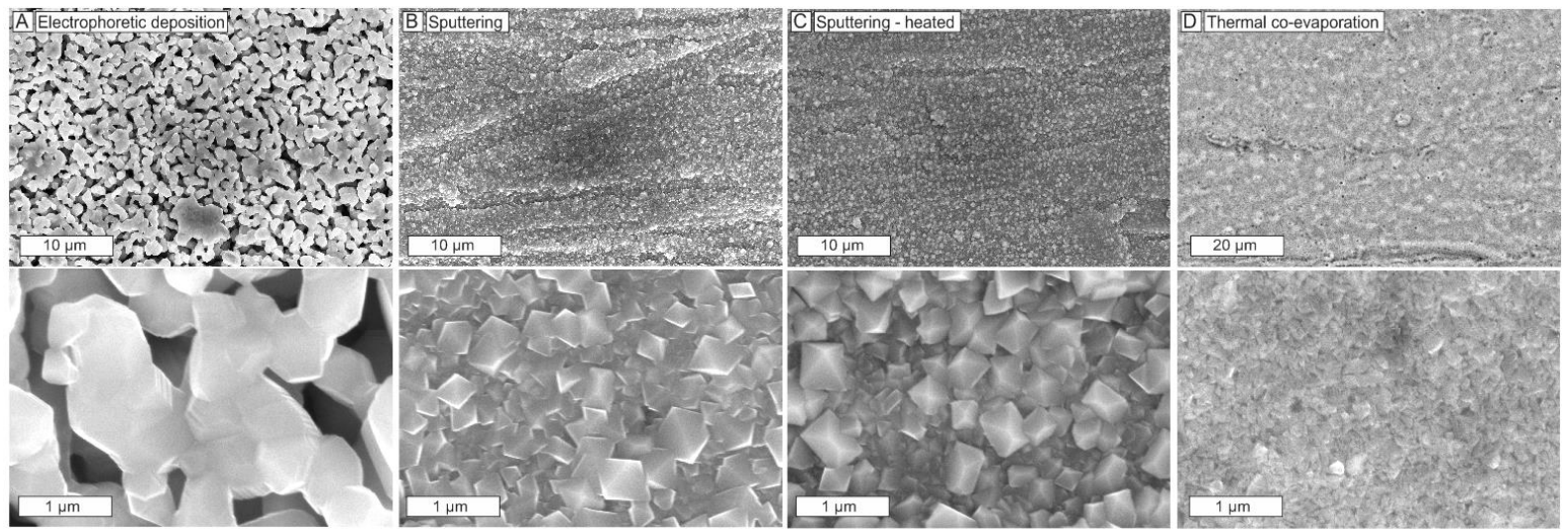

Figure 2. Surface SEM images of the as-prepared Mn-Co spinel coatings. 

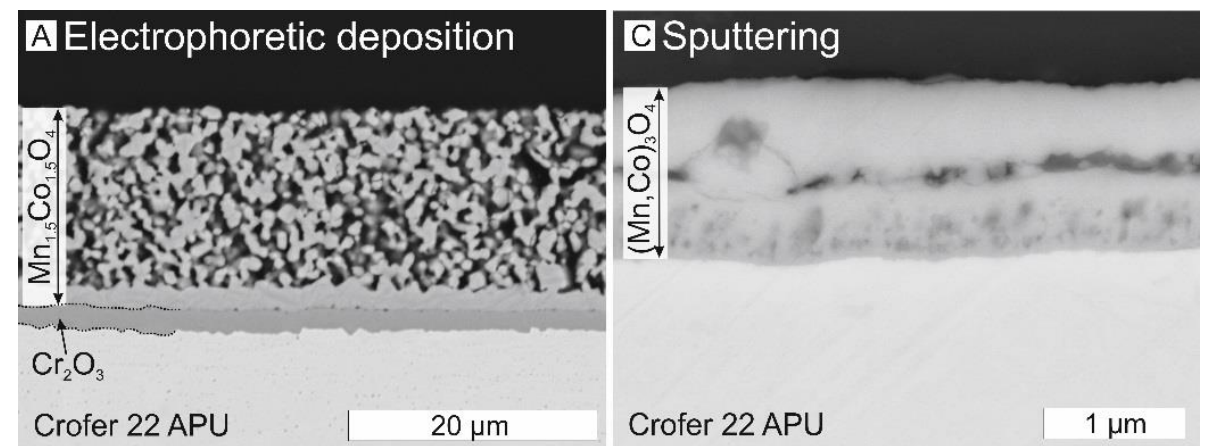

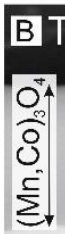

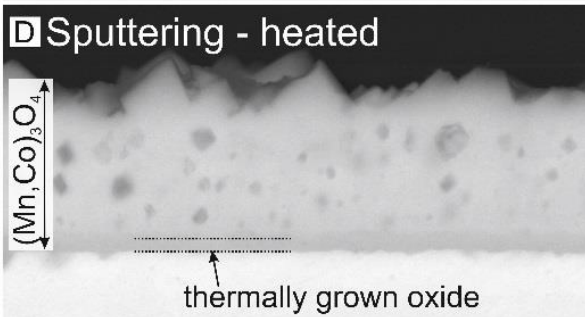

Crofer 22 APU

$1 \mu \mathrm{m}$

Crofer $22 \mathrm{APU}$

$1 \mu \mathrm{m}$

Figure 3. Cross section SEM images of the as-prepared Mn-Co spinel coatings. Please note a different magnification of Figure A.

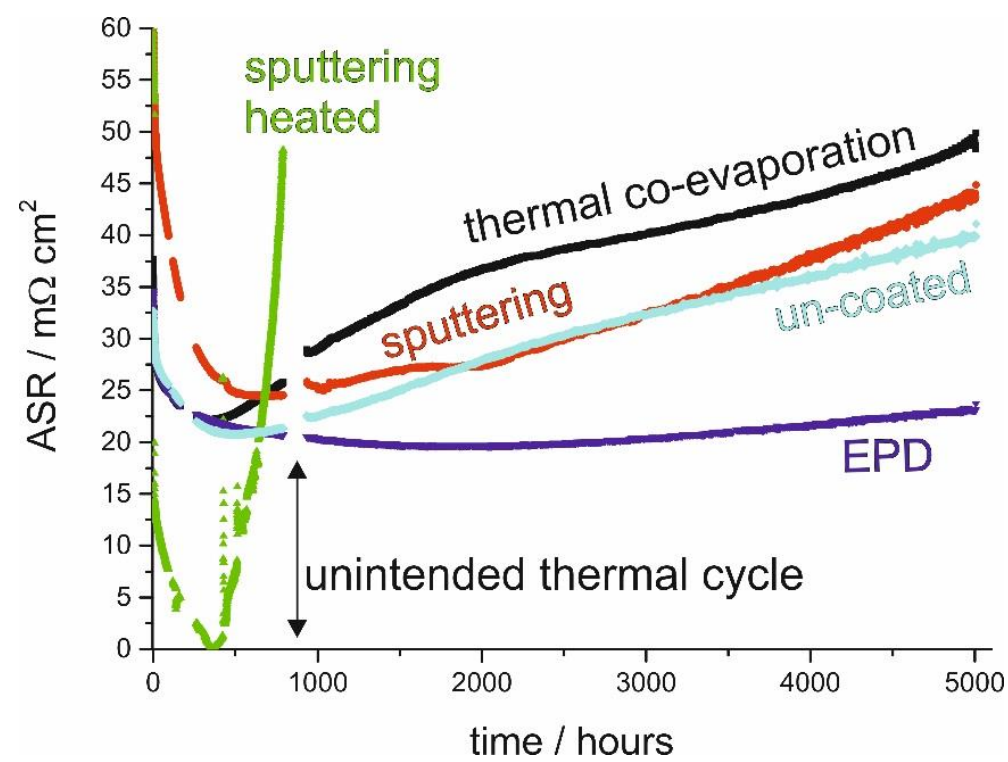

Figure 4. Area Specific Resistance measurement of samples at $800^{\circ} \mathrm{C}$ under a current load of $500 \mathrm{~mA} \mathrm{~cm}^{-2}$. 

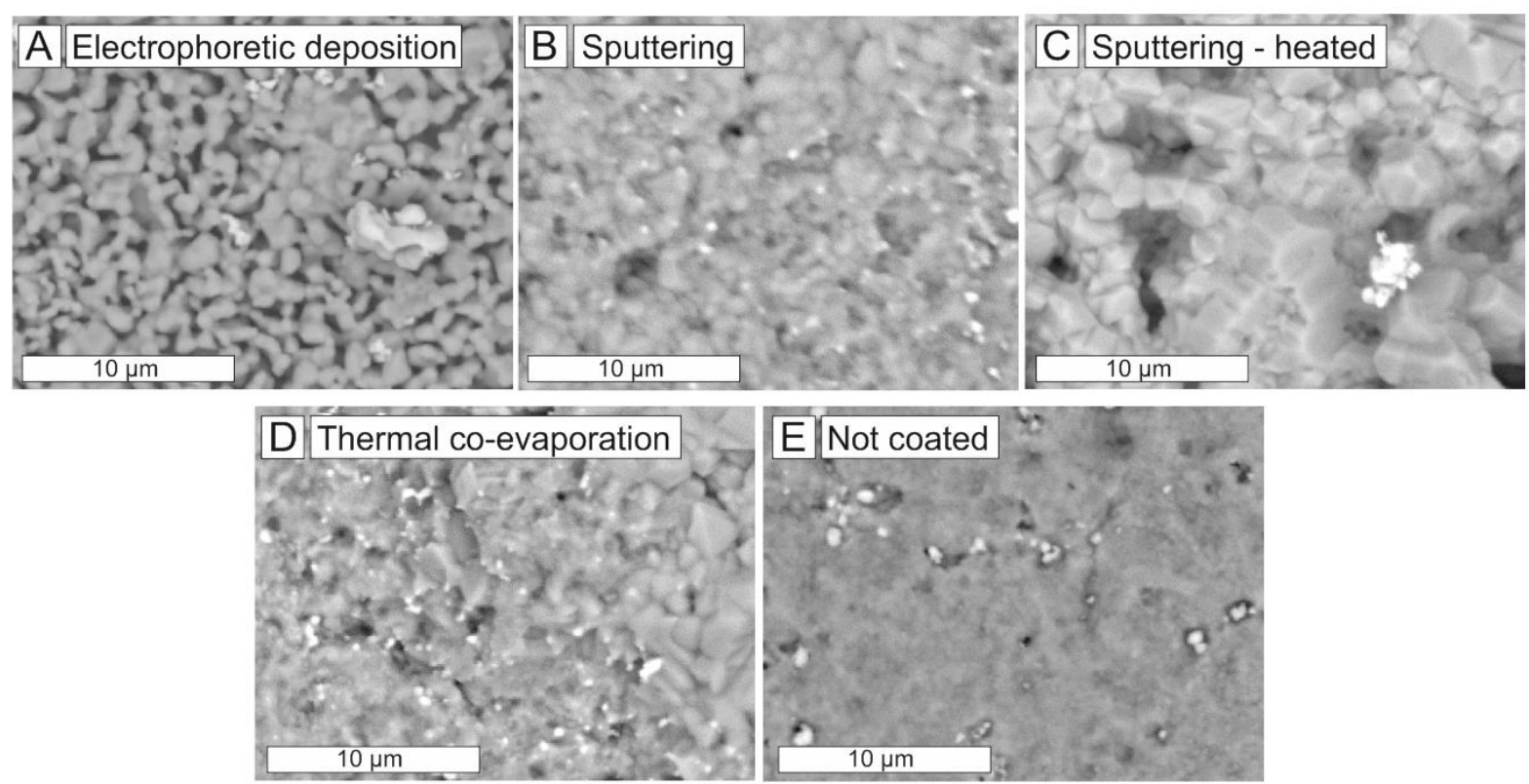

Figure 5. Surface analysis of the samples after the ASR measurement.

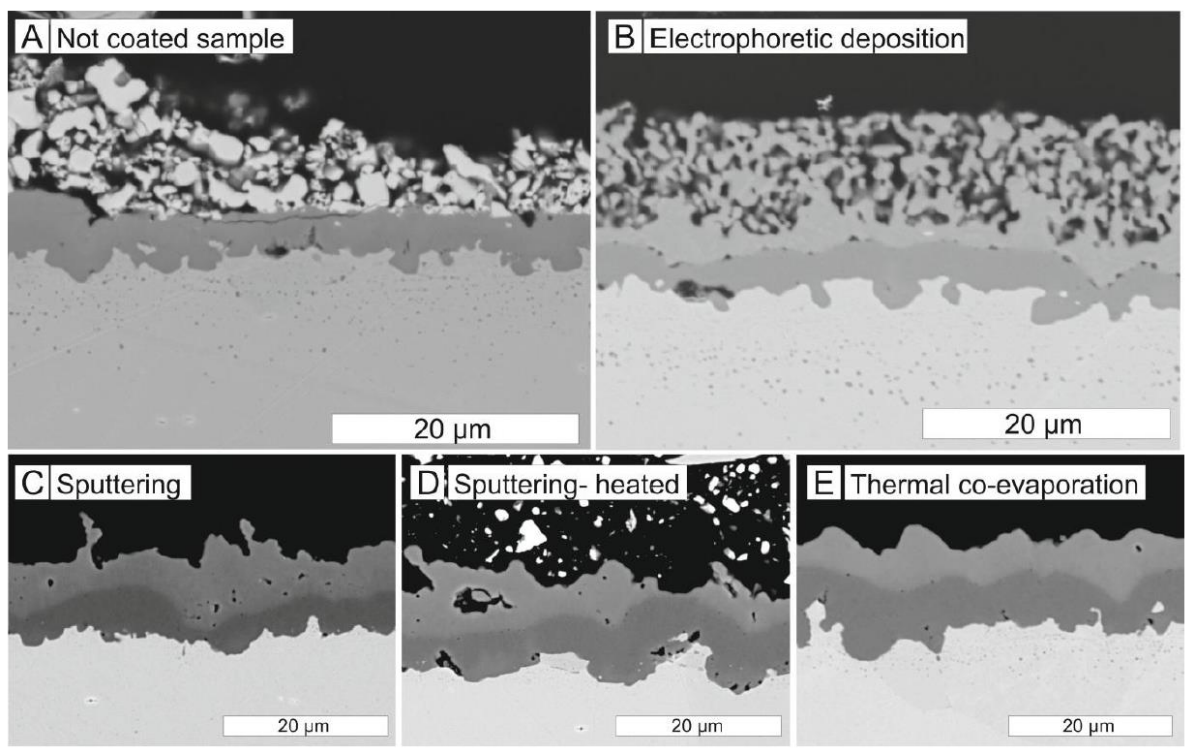

Figure 6. Cross section SEM images of all samples after 5000 hours electrical measurement. 

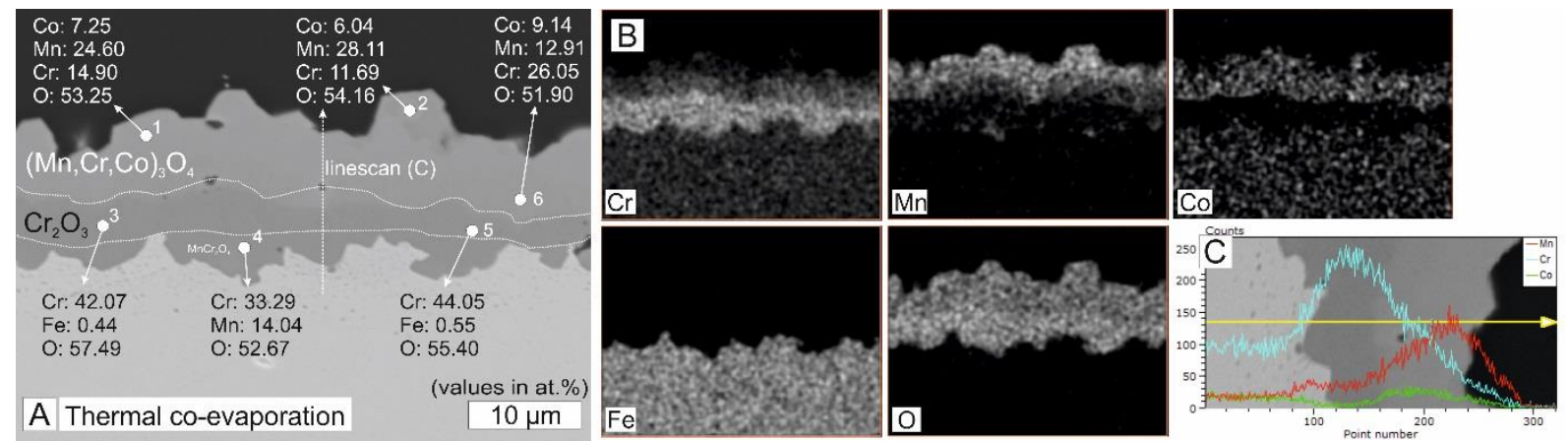

Figure 7. Cross section image (A) and EDS Cr-Mn-Co-Fe-O elemental maps (B) with a EDS linescan

(C) of a thermal co-evaporated sample after 5000 hours measurement. Compositions in A are given in at.\%.
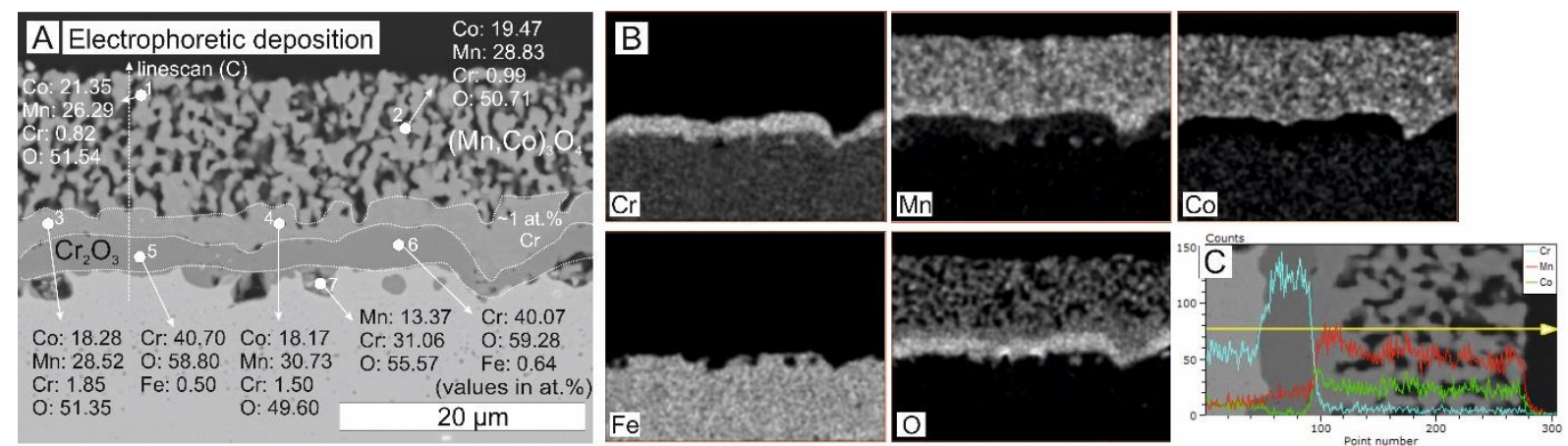

Figure 8. Cross section image (A) and EDS Cr-Mn-Co-Fe-O elemental maps (B) with a EDS line scan (C) of the electrophoretically deposited sample after 5000 hours measurement. Compositions in A are given in at. $\%$. 


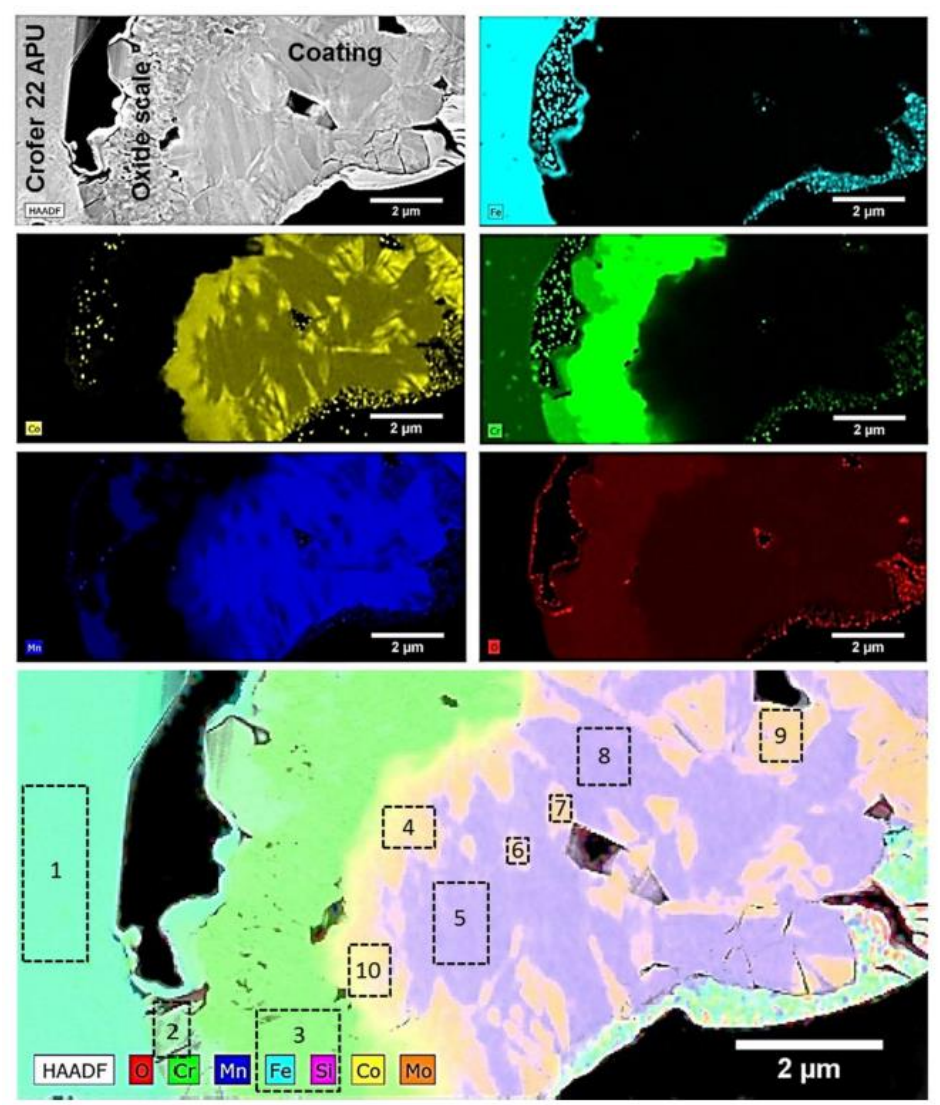

Figure 9. Transmission electron microscopy image of FIB lamella with EDS elemental analysis. Composition of marked areas is given in Table 1.

EPD COATING $(10-15 \mu \mathrm{m})$

A NO CONTACT WITH Mn SOURCE (LSM PLATE) AS-SINTERED SAMPLE

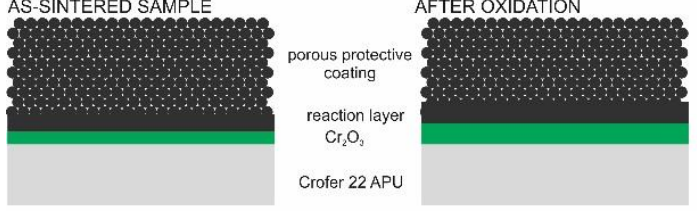

$\bar{B}$ CONTACT WITH Mn SOURCE (LSM PLATE)

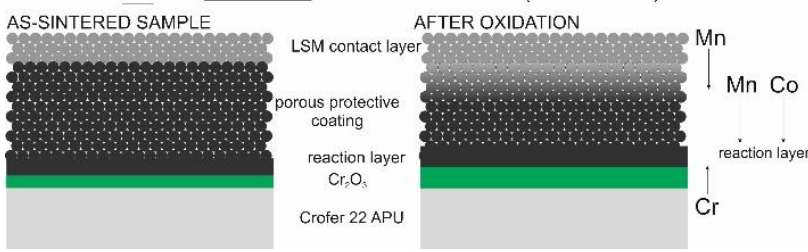

THIN COATINGS $(\sim 1 \mu \mathrm{m})$

C $\mid$ NO CONTACT WITH Mn SOURCE (LSM PLATE)

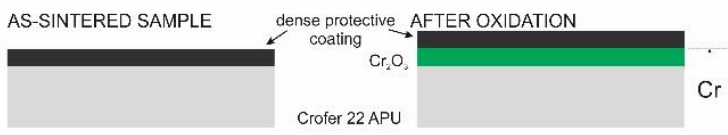

D CONTACT WITH Mn SOURCE (LSM PLATE)

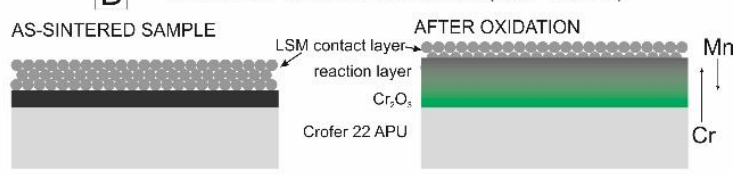

Figure 10. Schematic representation of reactivity of thin and thick Mn-Co coatings. 
Table 1. Chemical composition of areas studied by TEM-EDS shown in Figure 9.

\begin{tabular}{l|l|l|l|l|l}
\hline Area & $\begin{array}{l}\mathbf{F e} \\
\text { [at.\%] }\end{array}$ & $\begin{array}{l}\mathbf{C r} \\
\text { [at.\%] }\end{array}$ & $\begin{array}{l}\mathbf{O} \\
\text { [at.\%] }\end{array}$ & $\begin{array}{l}\mathbf{M n} \\
\text { [at.\%] }\end{array}$ & $\begin{array}{l}\text { Co } \\
\text { [at.\%] }\end{array}$ \\
\hline $\mathbf{1}$ & 74.9 & 22.3 & 1.3 & 0.2 & $\mathbf{1 . 1}$ \\
\hline $\mathbf{2}$ & - & 36.9 & 43.8 & 19.1 & - \\
\hline $\mathbf{3}$ & - & 52.7 & 47.3 & - & - \\
\hline $\mathbf{4}$ & $<1$ & 7.8 & 36.4 & 21 & $\mathbf{3 3 . 8}$ \\
\hline $\mathbf{5}$ & $<1$ & 1.1 & 36.6 & 40.8 & $\mathbf{2 0 . 4}$ \\
\hline $\mathbf{6}$ & $<1$ & $<0.5$ & 32.9 & 29.4 & $\mathbf{3 6}$ \\
\hline $\mathbf{7}$ & $<1$ & $<0.5$ & 35.8 & 25.5 & $\mathbf{3 7 . 5}$ \\
\hline $\mathbf{8}$ & $<1$ & $<0.5$ & 36 & 42 & $\mathbf{2 0}$ \\
\hline $\mathbf{9}$ & $<1$ & $<0.5$ & 36 & 23 & $\mathbf{3 7}$ \\
\hline $\mathbf{1 0}$ & $<\mathbf{1}$ & $\mathbf{7 . 4}$ & $\mathbf{3 6}$ & $\mathbf{2 0}$ & $\mathbf{3 4}$ \\
\hline
\end{tabular}

